\section{Gategory}

Organo- and Biocatalysis

\section{Key words}

desymmetrization

peptide catalysis

enzyme mimic

acetylation

SYNFACThenth

C. A. LeWis, A. ChiU, M. KUBRYK, J. BAlsells, D. POllard, C. K. ESSER, J. MURRY, R. A. REAMER, K. B. HANSEN,* S. J. MILLER* (YALE UNIVERSITY, NEW HAVEN, BOSTON COLLEGE, CHESTNUT HILL AND MERCK RESEARCH LABORATORIES, RAHWAY, USA) Remote Desymmetrization at Near-Nanometer Group Separation Catalyzed by a Miniaturized Enzyme Mimic J. Am. Chem. Soc. 2006, 128, 16454-16455.

\title{
Remote Desymmetrization: Peptide versus Enzyme Catalysis
}
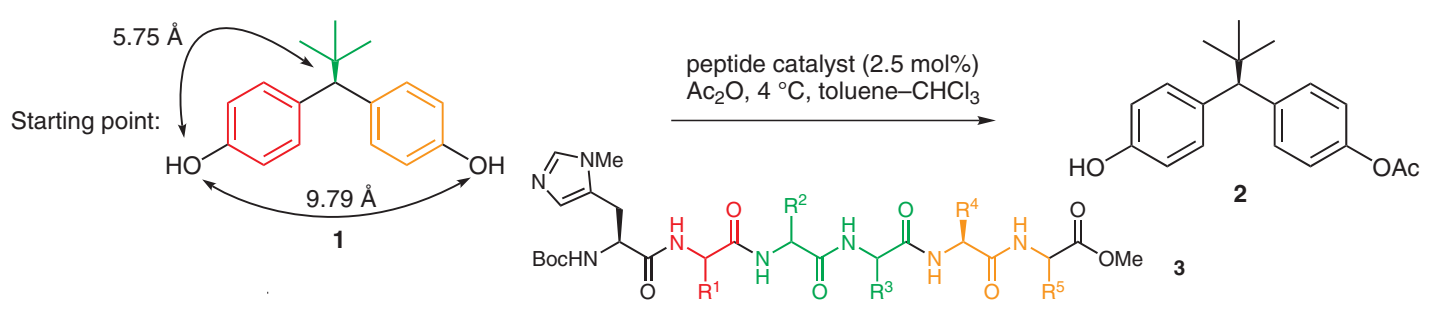

(truncation study

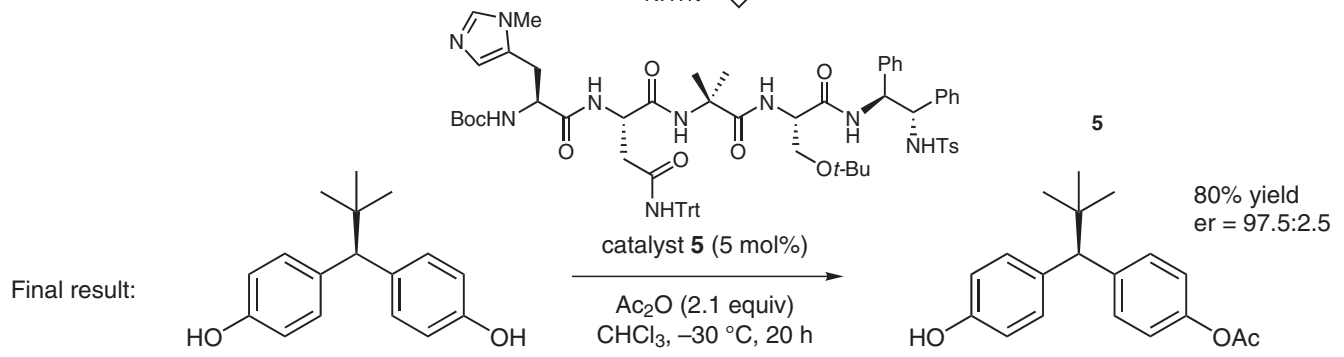

Significance: A catalytic protocol for the unprecedented remote asymmetric desymmetrization of bis(phenol) 1 via peptide-catalyzed monoacetylation has been developed. Since the desired site of functionalization is $>5.7 \AA$ from the 'prochiral' stereogenic center and the enantiotopic oxygen atoms are separated by a near-nanometer span, bis(phenol) 1 represents a particulary challenging substrate. After an examination of libraries of hexameric peptides $\mathbf{3}$, whose residue pattern was chosen as a mirror image of the alternating aromatic-aliphatic-aromatic nature of substrate $\mathbf{1}$, and followed by a truncation study of lead catalyst $\mathbf{4}$, tetramer $\mathbf{5}$ was identified as the best catalyst, delivering monoacetylated product 2 in $80 \%$ yield and with an er of 97.5:2.5.

SYNFACTS Contributors: Benjamin List, Corinna Reisinger Synfacts 2007, 3, 0324-0324 Published online: 20.02.2007 Dol: 10.1055/s-2007-968232; Reg-No.: B00407SF
Comment: Often enzymes are employed as chiral catalysts when facing a challenging problem for enantioselective catalysis. Due to their molecular complexity they are able to induce chirality over substantial distances. In the present example, however, the small tetramer $\mathbf{5}$ was superior to more than 450 enzymes screened in the asymmetric hydrolysis of the bis(acetate) of $\mathbf{1}$. In contrast to enzymatic catalysis, which leads to reasonable enantioselectivities only through secondary kinetic resolution of monoacetate $\mathbf{2}$, the selectivity in the peptide-catalyzed version is dominated by enantiotopic group discrimination. Potential for enantioselective recognition, a property typically inherent in enzymes, was observed by ${ }^{1} \mathrm{H}$ NMR spectroscopy. Association of peptide catalyst $\mathbf{5}$ with bis(phenol) 1 caused the loss of degeneracy of the phenol moieties. 